\title{
THE APPLICABILITY OF THEORY OF PLANNED BEHAVIOUR TO PREDICT DOMESTIC TOURIST BEHAVIOURAL INTENTION: THE CASE OF BANGLADESH
}

\author{
Abdulla Al-Towfiq HASAN \\ Patuakhali Science and Technology University, Faculty of Business \\ Administration and Management, Department of Marketing, Bangladesh, e-mail: towfiqhasan.du@gmail.com
}

Chhanda BISWAS*

Universiti Utara Malaysia, College of Law, Government and International Studies, School of Tourism,

Hospitality and Environmental Management, 06010, Kedah, Malaysia, e-mail: chhandabiswasuum@gmail.com

Moumita ROY

Habbibullah Bahar University College, Department of BBA Professional, Santinagar, Dhaka, Bangladesh, e-mail: moumita058@yahoo.com

\author{
Sonia AKTER
}

Shaikh Burhanuddin Post Graduate College, Department of Tourism and Hospitality Management, Dhaka, Bangladesh, e-mail: soniaduthm@gmail.com

\section{Bapon Chandra KURI}

Bangabandhu Sheikh Mujibur Rahman Science and Technology University, Department of Tourism and Hospitality Management, Dhaka, Bangladesh, e-mail: baponchandra@gmail.com

Citation: Hasan, A.A., Biswas, C., Roy, M., Akter, S., \& Kuri, B.C. (2020). THE APPLICABILITY OF THEORY OF PLANNED BEHAVIOUR TO PREDICT DOMESTIC TOURIST BEHAVIOURAL INTENTION: THE CASE OF BANGLADESH. GeoJournal of Tourism and Geosites, 31(3), 1019-1026. https://doi.org/10.30892/gtg.31313-536

\begin{abstract}
The paper aims at expanding the TPB model to examine the relationship among attitude, subjective norms, perceived behavioural control, motivation, and behavioural intention as well as the extent to which satisfaction mediates the relationship in the link between TPB predictive constructs along with motivation and behavioural intention. A questionnaire survey technique was administered on domestic tourists and subsequently, structural equation modeling using SmartPLS 3.0 was subjected to test the synthesized relationship among va riables. The study findings support that attitude, subjective norms, and motivation significantly influence customer satisfaction and behavioural intention whereas perceived behavioural control does not. In addition, the study indicates that customer satisfaction mediates in the link betw een attitude, subjective norms, and motivation, and behavioural intention. However, despite the availability of international tourists, the study selected only domestic tourists that are liable for future research. Moreover, the findings of the study will enhance the understanding of hospitality researchers and managers what will significantly influence customer satisfaction and behavioural intention.
\end{abstract}

Key words: Attitude, subjective norms, perceived behavioural control, motivation, behavioural intention, domestic tourists

$* \quad * \quad * * * * *$

\section{INTRODUCTION}

Although behavioural intentions have been considering the most important study area in tourism literature for the last decades, motivation including other factors is considered as dominant predictors to it as well (Doane et al., 2014). Understanding factors influencing tourist behavioural intentions of selecting a tourist destination signifies on the travel industry promoting and advancement. The tourist decision-making process of selecting a tourist spot is a perplexing procedure (Kautonen et al., 2015). With the end goal of exploring this procedure, the theory of planned behaviour (TPB) model along with motivation and satisfaction as a proposed conceptual framework is applied to anticipate behavioural intention of selecting a tourist spot.

Furthermore, TPB has been used as a strong predictor for measuring a variety of social behaviours since its development (Ajzen, 1991; Alam and Sayuti, 2011). Lam and Hsu (2004) argued that the predictive power of TPB might be enhanced by using additional constructs with it. To investigate it, the study applied motivation as a predictive construct and satisfaction as a mediator to identify tourist behavioural intentions. Although motivation influences an individual tourist, satisfaction had found as both direct and indirect effects on behavioural intentions of an individual in previous literature (Chen and Chen, 2010; Eusébio and Vieira, 2011; Wu et al., 2014). But very few studies have found satisfaction as the mediator to measure behavioural intention adopting the TPB model. Hence, satisfaction was proposed as a mediator in the research framework to predict behavioural intentions of choosing a travel destination.

\section{LITERATURE REVIEW}

\section{Theory of planned model}

Many studies identified that the TPB model is the extension of the theory of reasoned action or the TRA model (Paul et al., 2016; Armitage and Christian, 2017; Sheeran and Abraham, 2017). Martin Fishbein and Ice Ajzen developed the TRA model that has been used as a tool to investigate human behaviour in marketing and psychological disciplines (Doane et al., 2014; Mishra et al., 2014). However, though TRA was developed to explicitly explain volitional behaviours, the TPB was proposed to predict behaviours that are not under completely volitional control (Cheon et al., 2012; Kautonen et al., 2015). The TPB model includes additionally perceived behavioural control (Armitage and Christian, 2017). TPB postulates that behavioural intention is the consequence of attitudes, subjective norms, and perceived behavioural control (Ajzen, 2015). For anticipating behavioural intentions and behaviours, this theory is utilized. Li and Cai (2012); Jin et al. (2015)

\footnotetext{
${ }^{*}$ Corresponding author
} 
indicated that it has strong predictive utility applied to situations that do not fall within the boundary conditions. The theory centralizes the concept of intention (Sheeran and Abraham, 2017). Intention regards motivations engaged in a specific behaviour (Chen and Tung, 2014). An individual's intention to perform a specific act represents behavioural intention (Ifinedo, 2012).

\section{Behavioural intention}

Behaviour immediately determines and predicts behavioural intention (Cham et al., 2016). It is widely accepted that anticipated or planned future behaviour of an individual defines behavioural intention with expectations of a particular form of behaviour given and operationalized as the likelihood to act (Huang et al., 2015). Besides, if tourists get opportunities, they act according to their intention which provides the best predictor of behaviour (Cheng and $\mathrm{Lu}, 2015$ ). As per the tourism literature, tourist behavioural intention toward a specific tourist spot is mainly the outcome of the two factors (Prayag and Ryan, 2012). First, push factors, which represent socio-physiological motivations and cognitive processes originated from the intangible desires of human beings (Abubakar and Ilkan, 2016). These factors include desires rest, relaxation, physical and mental fitness, adventure, novelty, prestige, and socialization (Abubakar and Ilkan, 2016). Second, pull factors, which represent tangible and intangible cues of a tourist spot's attractiveness originated after decisions are made to visit (Bodycott and Lai, 2012). These factors include recreation facilities, natural attractions, historic attractions, food quality and variety, image and transport facilities (Cohen et al., 2014). In line with the above discussion, an individual tourist behavioural intention results from experiences after services encounter (Jin et al., 2015). When an individual tourist has positive experiences, then he/she has positive behavioural intentions. Conversely, if an individual tourist has negative experiences, then he/she has negative behavioural intentions towards a particular tourist spot (Dolnicar, 2010). Hence, previous studies show that an individual tourist's experience is not merely enough to predict behavioural intention towards tourist spot in Bangladesh (Wu et al., 2014). Rather, tourist attitude is the most valid predictor that effectively predisposes to behavioural intention towards tourist spot in Bangladesh (Ghosh et al., 2018).

\section{Attitudes}

It is widely accepted that the tourist attitude comprises cognitive, affective, and behavioural components (Page et al., 2014). However, an individual tourist's attitude is estimated by multiplying an individual's behavioural beliefs with salient attributes of each tourist (Paul et al., 2016). Furthermore, when an individual tourist has a more positive attitude, he/she shows more positive behavioural intentions (Wang, 2016). Hence, tourist attitude signifies the most valid predictor of tourist future behaviour and additionally, represents internal behaviour that can influence an individual's external behaviour (Kim and Stepchenkova, 2015). Conversely, previous studies show that exploring a tourist spot in Bangladesh, tourist attitude is not the mere valid predictor to predisposing behavioural intention; rather an individual tourist who has the stronger subjective norms the more positive behavioural intention towards the tourist spot (Hassan and Shahnewaz, 2014).

\section{Subjective norms}

Subjective norm reflects an individual's normative beliefs (Chan et al., 2015). Besides, subjective norms play an important role in influencing individual's decision-making process (Chang et al., 2016). Furthermore, most past researches confirmed that behavioural intention is positively affected by individual's subjective norms when the relationship between the behavioural intention and individual's subjective norms is examined (Kumar et al., 2015; Ye, 2017). Thus, the stronger individual's intention to act depends on, the more positive subjective norms he/she has. However, though the subjective norm represents the significant predictor of behavioural intention (Ye, 2017), tourist's perceived behavioural control ultimately controls individual tourist's behavioural intentions and leads to taking final consumption decisions of tourists in Bangladesh (Hossain et al., 2018).

\section{Perceived behavioural control}

According to Jin et al. (2015), tourists ' perceived behavioural control represents the degree of an individual's perception of possibilities/ difficulties of performing a specific behaviour. Besides, it comes from control beliefs and a multiplicative combination of perceived behavioural control components (Chen and Tung, 2014). Most of the studies concluded that the relationship between tourist's perceived behavioural control and behavioural intention is inferred based on two assumptions. First, when an individual tourist's perceived behavioural control increases, the result of the likelihood of visiting a particular spot will increase (Lam and Hsu, 2006). Second, an individual tourist's perceived behavioural control will effectively control an individual tourist's behavioural intention when perceived control reflects the actual control (Kim, 2012). However, Hsu and Huang (2012) argued that the factors including chance, money, etc. may not be considered as a part of an individual tourist's behavioural control. Therefore, the more an individual tourist has control over resources, opportunities, and time, the more likely to have an individual tourist's behavioural intention to visit in a specific spot (Sahli and Legohérel, 2014). Conversely, previous studies found that examining the behavioural intention of tourists who love adventures, education, relaxation, knowledge, and serenity, etc., tourist's motivation is the valid predictor to behavioural intention towards tourist spot in Bangladesh (Hassan and Shahnewaz, 2014; Kamal et al., 2015).

\section{Tourist Motivation}

In tourist behaviour, tourist motivation is considered as a key driver because of the interrelationship between tourist's needs and motivation. Crompton (1979) developed a model of travel motivation. This model is called the push-pull model which identifies pushpull effects on the selection of a tourist spot. Consequently, push forces (needs, motives, and drives) make sure of leaving from home and seeking unspecified tourist spot for vacation and pull forces (advertising, destinations, and services) compel a tourist towa rd a perceived attractive destination (Kong and Chang, 2016). In addition, Dann (2012) argued that individual tourist visits a tourist spot for knowledge, relaxation, social relationship development, etc. Moreover, Rajesh (2013) found that examining tourist motivation is complex in nature. Tourist motivation comprises physical, cultural, interpersonal status, and prestige constructs. Furthermore, knowledge, punishment minimization, ego enhancement, reward maximization, and self-esteem measure tourism motivation. Additionally, tourist motivation is categorized into social motivation and spot attraction in Bangladesh (Wu and Pearce, 2014; Hassan and Shahnewaz, 2014).

In line with the above discussion, tourist motivation can be classified as education, adventure, and holistic approach of ecotourism motivation in a coastal tourist spot in Bangladesh (Hassan and Shahnewaz, 2014). Nature-based tourist studies of Bangladesh suggest that tourist motivation comprises physical, social contract, novelty-seeking, mundane every day, to be nature, and ego/status components (Xu and Chan, 2016). However, tourist motivation that comes from novelty regression, cultural exploration, gregariousness at festival events, and external interaction is not only the sole predictor of behavioural intention but also tourist satisfaction is an effective predictor of behavioural intention (Wu and Pearce, 2014). 


\section{Tourist Satisfaction}

Chand and Ashish (2014) identified that an individual tourist becomes satisfied only if the attributes of a tourist spot can make him/her positive experiences. Consequently, travel experiences, return travel facilities, time consumption is the valid indicator of tourist satisfaction (Biodun, 2014). In addition, most of the studies indicated that an individual tourist's onsite recreational experiences are positively correlated with tourist satisfaction. Moreover, Chi and Qu (2008) discussed that several paradigms are used to explain the tourist satisfactions of which two are important approaches to explaining the decision making process. First, the cognitive approach which represents knowledge/beliefs comes from an individual tourist's experiences. Second, the emotional approach comprises sensory pleasures, daydreams, and enjoyment based on the assumption that creates positive experiences. However, typically tourist satisfaction is measured by a common method that applies multi-item scales that comprises service quality, adventure experiences, recreational program, river watching facilities, safety equipment, ecology, and landscape constructs (Durie and Kebede, 2017).

In line with the above paradigms, most previous studies found that tourist satisfaction is the result of the summation of past positive experiences minus negative experiences fulfilling an individual tourist's needs (Huang, 2014). Furthermore, tourist satisfaction represents the most influential factor leading to tourist behavioural intention in Bangladesh (Hassan and Shahnewaz, 2014).

\section{Proposed Research Model}

The TPB model has attitudes, subjective norms, and perceived behavioural control as correlated exogenous constructs leading to intentions and behaviour. As such, the theory does not specify the relationship among these variables and any other variables outside the model. Thus, the relationship between the variables of the proposed extended model must be specified.

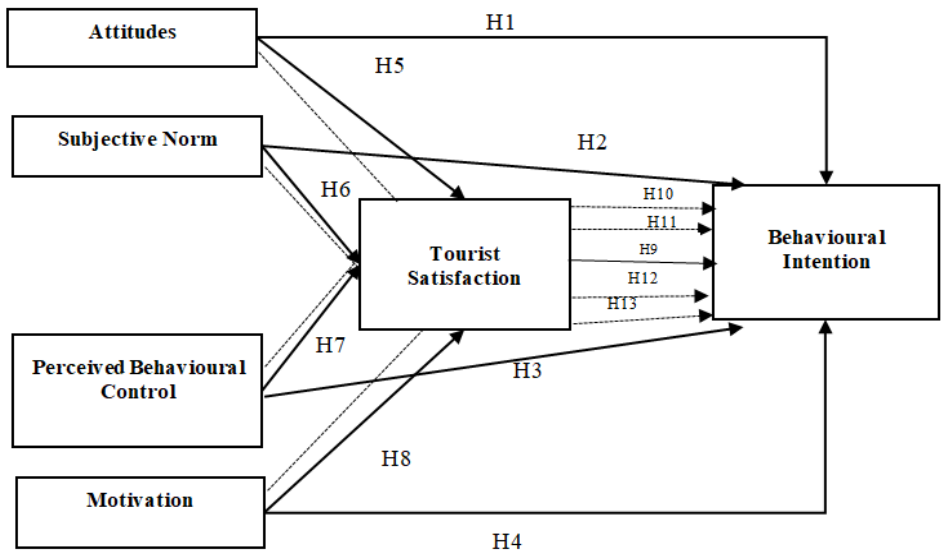

Figure 1. Conceptual framework of customer's behavioural intentions

\section{HYPOTHESIS DEVELOPMENT}

Several studies have argued that attitudes, subjective norms, and perceived behavioural control have direct correlations with behavioural intentions (Ajzen, 1991). To estimate these, Bagozzi (1981) found that attitude has a direct effect on behavioural intentions. Similarly, Liao et al. (2007) found that subjective norms and perceived behavioural control positively influence on behavioural intentions. Therefore, it was postulated that:

H1: Attitudes will have a significant effect on tourist behavioural intentions.

H2: Subjective norms will have a significant effect on tourist behavioural intentions.

H3: Perceived behavioural control will have a significant effect on tourist behavioural intentions.

However, motivation which is a strong predictor of behavioural intentions sufficiently presses to seek satisfaction. Kolvereid (1996) argued that motivation has a direct influence on a person's behavioural intentions. Thus, it was hypothesized that:

H4: Motivations will have a positive impact on a person's behavioural intentions.

In line with the previous discussion, few studies found that attitudes, subjective norms, perceived behavioural control, and motivation have direct effects on satisfaction. To examine this, Manning (2009) found that subjective norm has a direct relationship with satisfaction, and Liu et al., (2006) indicated that perceived behavioural control as a significant factor to satisfaction. As a result, it was hypothesized that:

H5: Attitudes will have a positive impact on a person's satisfaction.

H6: Subjective norms will have a positive impact on a person's satisfaction.

H7: Perceived behavioural control will have a positive impact on a person's satisfaction.

H8: Motivations will have a positive impact on a person's satisfaction.

Previous studies also found that satisfaction has a direct relationship with behavioural intentions (Liao et al., 2007; Biodun, 2014). Therefore, it was postulated that:

H9: Tourist satisfaction will have a positive impact on a person's behavioural intentions.

No studies have examined the impact of satisfaction as a mediator between TPB constructs (attitudes, subjective norms, and perceived behavioural control) along with motivation and behavioural intentions, although the strength of associations between these variables is quite high (Manning, 2009). Thus, it was hypothesized that:

H10: Attitudes will have a positive impact on a person's satisfaction toward behavioural intentions.

H11: Subjective norms will have a positive impact on a person's satisfaction toward behavioural intentions.

H12: Perceived behavioural control will have a positive impact on a person's satisfaction toward behavioural intentions.

H13: Motivations will have a positive impact on a person's satisfaction toward behavioural intentions.

\section{RESEARCH METHODOLOGY}

\section{Sampling Design and Data Collection}

Respondents were first asked to recall whether they visited any tourist spot at least once in life in Bangladesh or not. The matter was encouraged to remember because the study was conducted to measure the behavioural intentions of domestic tourists in Bangladesh. To carry 
out the study, 800 questionnaires in Google drive link format were purposively distributed through an email address and Facebook to respondents who were undergraduate and graduate students, Government, and private employees, and aged between 18 and 65 over two months from 31 October to 31 December. Online survey through sending Google drive link is very much popular among undergraduate and graduate students as well as employees because they can fill it up on their convenience time. Of the 800 respondents, 412 filled up the questionnaires. Of 412 questionnaires, 303 were valid returns to be analysed but the rest was not. The sample was split into male and female. Of the 303 respondents, 154 were male and 149 were female. Of the 303 , most of the respondents (113) were aged between 26 and 40 . Of the 303 , most of the respondents (224) travelled to the tourist destination independently. In line with these, most of the respondents travel with family (135) and friends (135) and most of them (153) stay within 3-4 days.

Tourism Board of Bangladesh reveals that Bangladesh has more than 100,000 domestic tourists (Bangladesh Tourism Board, 2020). According to Krejcie and Morgan's (1970) table, 303 respondents represent populations. In the last decade, citizens aged between 26 and 55 are the main domestic tourist of Bangladesh (Bangladesh Tourism Board, 2020). Moreover, undergraduate and graduate students are also one of the main domestic tourists ('Bangladesh Tourism Board', 2016). Hence it is to say that both students and employees aged between 26 and 40 have more behavioural intentions toward tourist destinations.

\section{Measures}

The measurement scales used for the studied constructs in this study were validated in previous studies. Intending to conduct the study, researchers used questionnaire items from different authors. Carrying out the study, four items were used to measure the attitude of which three were adapted by Ziadat (2015) and rest one was adapted by Lam and Hsu (2006); four items were used to measure subjective norms of which two were adapted by Ziadat (2015) and the other two were adapted by Phetvaroon (2006); four items were used to measure perceived behavioural control of which three were adapted by Ziadat (2015) and the rest was adapted by Phetvaroon (2006); five items were used to measure the motivation of which three were adapted by Yao (2013) and the rest was adapted by (Lee, 2009); five items were used to measure customer satisfaction adapted by (Yao, 2013); and four items were used to measure customer behavioural intentions adapted by Phetvaroon (2006) and slightly modified into the context for predicting behavioural intentions towards the tourist spot in Bangladesh. All studied constructs were measured by a five-point Likert scale from "strongly disagree" to "strongly agree".

\section{RESULTS AND DATA ANALYSIS}

Of the 303, most of the respondents (224) travelled to the tourist destination independently. In addition, most of the respondents travel with family (135) and friends (135) and most of them (153) stay in tourist destinations within 3-4 days. However, the other demographic characteristics are presented in Table 1 .

Table 1. Descriptive Statistics of the Demographic Variables

\begin{tabular}{|c|c|c|c|c|}
\hline No & Characteristics & Variable & $N$ & $\%$ \\
\hline \multirow{2}{*}{1} & \multirow{2}{*}{ Gender } & Male & 154 & 50.8 \\
\hline & & Female & 149 & 49.2 \\
\hline \multirow{4}{*}{2} & \multirow{4}{*}{ Age } & 25 or below & 56 & 18.5 \\
\hline & & $26-40$ & 113 & 37.30 \\
\hline & & $41-55$ & 86 & 28.40 \\
\hline & & $56-65$ & 48 & 15.80 \\
\hline \multirow{2}{*}{3} & \multirow{2}{*}{ Type of travelling } & By agency & 79 & 26.10 \\
\hline & & Independent/FIT & 224 & 73.90 \\
\hline \multirow{4}{*}{4} & \multirow{4}{*}{ Travelling with whom } & Alone & 17 & 5.60 \\
\hline & & With family & 135 & 44.60 \\
\hline & & With friends & 135 & 44.60 \\
\hline & & With colleagues & 16 & 5.30 \\
\hline \multirow{4}{*}{5} & \multirow{4}{*}{ Length of stay } & 2 & 28 & 9.20 \\
\hline & & $3-4$ & 153 & 50.50 \\
\hline & & $5-7$ & 94 & 31.00 \\
\hline & & Over 7 & 28 & 9.20 \\
\hline
\end{tabular}

\section{Measurement Model}

To examine the appropriateness of research constructs, reliability, and construct validity were examined before testing the hypotheses. The reliability which represents internal consistency was tested by using composite reliability and Cronbach's alpha (Cronbach, 1951). The table 2 shows that studied constructs have Cronbach's alpha value is in a range between 0.766 and 0.908 and Fornell's composite reliability scores are greater than .80 indicates adequate internal consistency. To examine the construct validity, convergent and discriminant validity were measured. Neither of measures alone is sufficient to measure the construct validity. Convergent validity represents the measure of the constructs that theoretically remain related to each other (Bland and Altman, 1997). To examine the convergent validity, the Average variance extracted (AVE) scores derived from items loading were measured. Table 2 shows that studied constructs have AVE scores in the range between 0.571 and 0.732 which are greater than .50 indicates adequate internal consistency.

Table 2. Result of a measurement model for the study

\begin{tabular}{|l|l|c|c|c|}
\hline \multicolumn{1}{|c|}{ Latent variables } & Cronbach's Alpha & Rho_A & Composite Reliability & Average Variance Extracted (AVE) \\
\hline Attitudes & 0.870 & 0.881 & 0.911 & 0.720 \\
\hline Customer Behavioural Intention & 0.766 & 0.767 & 0.851 & 0.587 \\
\hline Customer Satisfaction & 0.811 & 0.815 & 0.869 & 0.571 \\
\hline Motivation & 0.908 & 0.909 & 0.932 & 0.732 \\
\hline Perceived Behavioural Control & 0.821 & 0.830 & 0.882 & 0.654 \\
\hline Subjective Norms & 0.814 & 0.813 & 0.878 & 0.644 \\
\hline
\end{tabular}

Conversely, discriminant validity defines the measure of the constructs that do not theoretically remain related to each other. To test the discriminant validity, further AVE can be used. That is to achieve discriminant validity in this model, the studied constructs must have a 
higher square root of AVE than the variance shared between the constructs and other constructs. Table 3 shows that the square root of AVE of studied constructs is higher than the correlations. Thus, the proposed model has achieved discriminant validity.

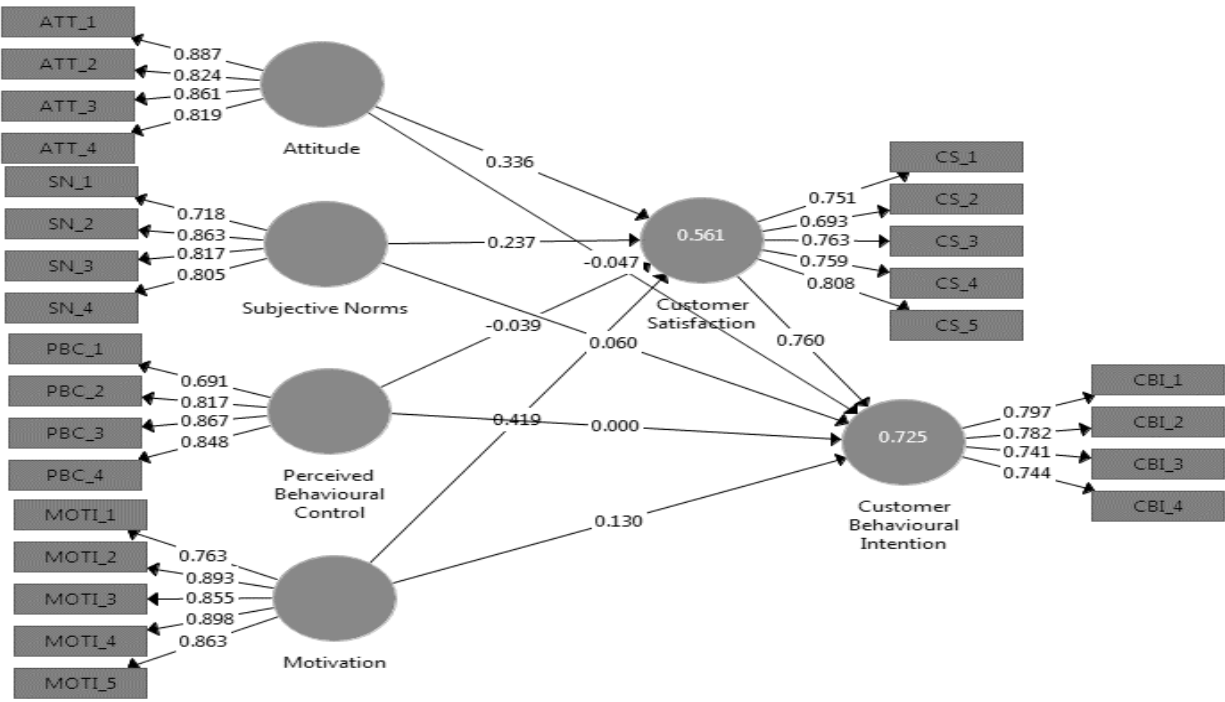

Figure 2. Diagram for the measurement model of the study

Table 3. Latent variable correlations, square roots of average variance extracted and AVE

\begin{tabular}{|l|l|l|l|l|l|l|l|}
\hline Constructs & ATT & CBI & CS & MOTI & PBC & SN & AVE \\
\hline Attitudes & $\mathbf{0 . 8 4 8}$ & & & & & & 0.720 \\
\hline Customer Behavioural Intention & 0.458 & $\mathbf{0 . 7 6 6}$ & & & & & 0.587 \\
\hline Customer Satisfaction & 0.574 & 0.843 & $\mathbf{0 . 7 5 6}$ & & & & 0.571 \\
\hline Motivation & 0.349 & 0.596 & 0.607 & $\mathbf{0 . 8 5 6}$ & & & 0.732 \\
\hline Perceived Behavioural Control & 0.041 & 0.180 & 0.165 & 0.316 & $\mathbf{0 . 8 0 9}$ & & 0.654 \\
\hline Subjective Norms & 0.394 & 0.472 & 0.506 & 0.351 & 0.245 & $\mathbf{0 . 8 0 2}$ & 0.644 \\
\hline
\end{tabular}

\section{Structural Model}

Through standardized path coefficients, t-statistics, and p-value, the structural model was examined. To estimate this SMART PLS 3.0 was used. Table 4 shows that ten hypotheses of thirteen are supported. H1, H2, and H4 predict that attitudes, subjective norms, and motivation have a direct positive effect on customer behavioural intention. The results support these hypotheses, because statistically significant relationship was found respectively $(\beta=0.208, t=3.613, p<0.001 ; \beta=0.0 .240, t=4.212, p<0.001 ; \beta=0.0 .449, t=7.918, p<0.001)$. Similarly, H3 predicts that perceived behavioural control has a positive effect on customer behavioural intention, but the result does not support the hypothesis. There was found no significant relationship $(\beta=-0.029, t=0.689, p>0.05)$.

Table 4. Results of the structural model of the study

\begin{tabular}{|c|c|c|c|c|c|}
\hline SL No. & Relationships & Direct/Indirect Effect & T Statistics & P-Value & Supported \\
\hline 1. & Attitude -> Customer Behavioural Intention & 0.208 & 3.613 & $0.000 * * *$ & Yes \\
\hline 2. & Attitude $->$ Customer Satisfaction & 0.336 & 6.291 & $0.000 * * *$ & Yes \\
\hline 3. & Customer Satisfaction -> Customer Behavioural Intention & 0.760 & 14.680 & $0.000 * * *$ & Yes \\
\hline 4. & Motivation -> Customer Behavioural Intention & 0.449 & 7.918 & $0.000 * * *$ & Yes \\
\hline 5. & Motivation -> Customer Satisfaction & 0.419 & 7.582 & $0.000 * * *$ & Yes \\
\hline 6. & Perceived Behavioural Control -> Customer Behavioural Intention & -0.029 & 0.689 & 0.491 & No \\
\hline 7. & Perceived Behavioural Control -> Customer Satisfaction & -0.039 & 0.936 & 0.349 & No \\
\hline 8. & Subjective Norms -> Customer Behavioural Intention & 0.240 & 4.212 & $0.000^{* * * *}$ & Yes \\
\hline 9. & Subjective Norms $->$ Customer Satisfaction & 0.237 & 4.234 & $0.000 * * *$ & Yes \\
\hline 10. & Attitude -> Customer Satisfaction -> Customer Behavioural Intention & 0.255 & 5.529 & $0.000^{* * * *}$ & Yes \\
\hline 11. & Motivation -> Customer Satisfaction -> Customer Behavioural Intention & 0.319 & 7.544 & $0.000 * * *$ & Yes \\
\hline 12. & Perceived Behavioural Control -> Customer Satisfaction -> Customer Behavioural Intention & -0.030 & 0.943 & 0.346 & No \\
\hline 13. & Subjective Norms -> Customer Satisfaction -> Customer Behavioural Intention & 0.180 & 4.016 & $0.000 * * *$ & Yes \\
\hline
\end{tabular}

Note: $\mathrm{p} \leq 0.01^{* * *} ; \mathrm{p} \leq 0.05^{* *} ; \mathrm{p} \leq 0.10^{*}$

Additionally, H5, H6, H7, and H8 predict that attitude, subjective norms, perceived behavioural control, and motivation have a direct positive effect on customer satisfaction. The results support $\mathrm{H} 5, \mathrm{H} 6$, and $\mathrm{H} 8$ because, the statistically significant relationship was found respectively $(\beta=0.336, t=6.291, p<0.001 ; \beta=0.237, t=4.234, p<0.001 ; \beta=0.419, t=7.582, p<0.001)$. Conversely, the result does not support $\mathrm{H} 7$, because no significant relationship was found $(\beta=-0.039, t=0.936, p>0.05)$. Hypothesis $\mathrm{H} 9$ predicts that customer satisfaction has a direct positive effect on customer behavioural intention. The result supports H9 because there was found a positive and statistically significant relationship $(\beta=0.760, t=14.680, p<0.001)$.

$\mathrm{H} 10, \mathrm{H} 11, \mathrm{H} 12$, and $\mathrm{H} 13$ predict that customer satisfaction has the mediating relationship in the link between attitude, subjective norms, perceived behavioural control, and motivation with customer behavioural intention. To investigate the mediation effect, all direct, indirect, and total effects between variables were measured. According to Baron and Kenny (1986) classic casual step approach, four conditions must be established to test the mediating effect: a direct link between dependent and independent variable; the mediating variable must be related with independent variable; when mediator and independent variable predisposed as predictors, the mediator must significantly affect dependent variable; and, the relationship between predictors and dependent variable must be significantly reduced when the mediator is 
added (Hosany and Prayag, 2013). The results of the study support H10, H11, and H13 because, the statistically significant relationship was found respectively $(\beta=0.255, t=5.529, p<0.001 ; \beta=0.180, t=4.016, p<0.001 ; \beta=0.319, t=7.544, p<0.001)$. Conversely, result does not support $\mathrm{H} 12$, because no significant relationship was found $(\beta=-0.030, t=0.943, p>0.05)$. Hence, the mediation analysis supports the partial mediation effect of customer satisfaction on TPB constructs along with motivation and customer behavioural intention.

\section{DISCUSSION AND CONCLUSION}

This research model was primarily developed to examine the relationship between motivation and satisfaction and the theory of planned behaviour (TPB) constructs. That is to investigate behavioural intention of choosing a travel destination, the study adopted the TPB model. Although the TPB model has been proved with new variables, motivation as a predictive construct is rarely included (Lee, 2009). In addition, satisfaction is not examined as a mediator between predictive variables of the TPB model along with motivation and behavioural intentions of the TPB model. The study was conducted through the motivation of a better understanding of how attitudes, subjective norms, perceived behavioural control, motivation, and satisfaction can lead to influence behavioural intention to choose a travel destination.

\section{Theoretical Implication}

In line with the above discussions, the study demonstrates the positive significant relationship between customer satisfaction and behavioural intention which is consistent with the previous literature (Manning, 2009; Liao et al., 2007; Liu et al., 2006). Furthermore, this study examined the mediating effect of satisfaction in the link between predictive constructs of the TPB model along with motivation and behavioural intentions. None of the previous studies examined this mediating relationship. Instead, satisfaction is investigated as a mediator between other variables such as satisfaction is investigated as a mediator in the link between service quality and loyalty (Águila-Obra et al., 2013), and satisfaction was found to mediate this relationship. Similarly, Albaity and Melhem (2017) examined the mediating relationship of satisfaction in the link between destination image along with novelty seeking and destination loyalty and found that satisfaction adequately mediates these relationships. Hence, this study adds a new contribution to the existing model, the TPB model.

\section{Managerial Implication}

The results of the study endow significant managerial implications. Tourist's attitude, subjective norms, and perceived behavioural control of choosing a travel destination are not enough for destination managers and planners who try to improve positive behavioural intentions. First, destination managers should enhance tourists' attitudes such as positive predisposition, positive feelings, positive positions in mind, etc. and subjective norms such as perceived influence from friends and family members. According to the statistical results, the present study shows that tourists' attitudes and subjective norms have a positive significant effect on behavioural intentions. Hence, the higher the positive attitudes and subjective norms indicate the higher their positive behavioural intentions of tourists toward destinations. Second, a travel destination must improve tourist motivation by adding motivating features involving safety, comfortable transportations, healthy foods, and comfortable accommodations (Pearce, 2014; Byrd et al., 2016). The statistical results of this study demonstrate that motivation can significantly influence on tourists' behavioural intentions. Therefore, it implies that the tourist who has a higher level of motivation has the higher positive behavioural intentions toward travel destination. Third, the destination marketers or managers must enhance tourists' satisfaction by providing some features including attractions, accessibility, dinging, environment, shopping, events, and activities (Rajesh, 2013). The statistical results shown in this study indicates the strong positive relationship between motivation and behavioural intentions. Hence, this study implies that satisfaction makes positive behavioural intentions towards tourist destinations.

Finally, the study assumes that satisfaction mediates in the link between attitudes, subjective norms, perceived behavioural control, and motivation with behavioural intention. Destination managers/marketers should improve the physical environment, food quality, image, and services, which dispose of positive perception to be satisfied leading to positive behavioural intention (Ryu et al., 2008). The statistical results of the study exert that satisfaction mediates between attitudes, subjective norms, and motivation, and behavioural intention. It can be consequently said that positive customers' attitudes, subjective norms, and motivation influence customer satisfaction leading positive behavioural intention. Apart from these, this paper will be helpful to tourism authorities because destination marketing can be successfully conducted by understanding tourists' attitude, satisfaction, and behavioural intentions about Bangladesh (Matlovičová and Husárová, 2017).

\section{Limitation and Suggestions}

Although the study has been carried out quantitatively, it has some limitations. The purposive sampling method and small sample size do not permit generalisation. In addition, motivation and satisfaction should be examined with more details in further research. Different interpretations and conceptualisations of motivation concepts are found in the marketing literature (Arifin, 2015). To investigate motivation, Lee (2009) added motivation as a new construct to predict satisfaction and motivation is highlighted in measuring behavioural intention as well. However, this study examined satisfaction as a mediator which is consistent with the previous study of Lee (2009) whereas satisfaction can bead as a moderator in future research. Furthermore, longitudinal field study can be conducted with an interval whereas the study was empirical study within two months. Additionally, this study was based on domestic tourists, which may not be a proper scientific approach whereas international tourists can be added to the study in future research.

\section{REFERENCES}

Abubakar, A.M., \& Ilkan, M. (2016). Impact of online WOM on destination trust and intention to travel: A medical tourism perspective. Journal of Destination Marketing and Management, 5(3), 192-201. https://doi.org/10.1016/j.jdmm.2015.12.005

Águila-Obra, A.R., Del, Padilla-Meléndez, A., \& Al-dweeri, R.M.O.O. (2013). The influence of electronic service quality on loyalty in postal services: The mediating role of satisfaction. Total Quality Management and Business Excellence, 24(9-10). https://doi.org/10.1080/14783363.2013.807681

Ajzen, I. (1991). The theory of planned behavior. Organizational Behavior and Human Decision Processes, 50(2), 179-211.

Ajzen, I. (2015). Consumer attitudes and behavior: The theory of planned behavior applied to food consumption decisions. Rivista Di Economia Agrariadi Economia Agraria, 70(2), 121-138. https://doi.org/10.13128/REA-18003

AL Ziadat, M.T. (2015). Applications of planned behavior theory (TPB) in Jordanian tourism. International Journal of Marketing Studies, 7(3), 95-106.

Alam, S.S., \& Sayuti, N.M. (2011). Applying the theory of planned behavior (TPB) in halal food purchasing. International Journal of Commerce and Management, 21(1), 8-20. https://doi.org/10.1108/10569211111111676

Albaity, M., \& Melhem, S.B. (2017). Novelty seeking, image, and loyalty-The mediating role of satisfaction and moderating role of length of stay: International tourists' perspective. Tourism Management Perspectives. Elsevier Ltd, 23. https://doi.org/10.1016/j.tmp.2017.04.001

Arifin, H.M. (2015). The influence of competence, motivation, and organisational culture to high school teacher job satisfaction and performance. International Education Studies, 8(1), 38-45. https://doi.org/10.5539/ies.v8n1p38 
Armitage, C.J., \& Christian, J. (2017). From attitudes to behaviour: Basic and applied research on the theory of planned behaviour. Current Psychology, 22(3), 187-195. doi: 10.4324/9781315126449-1.

Bagozzi, R.P. (1981). Attitudes, intentions, and behavior: A test of some key hypotheses. Journal of Personality and Social Psychology, 41(4), 607-627. https://doi.org/10.1037/0022-3514.41.4.607

Baron, R.M., \& Kenny, D.A. (1986). The moderator-mediator variable distinction in social psychological research: Conceptual, strategic, and statistical considerations. Journal of Penalty and Social Psychology, 51(6), 1173-1182.

Biodun, A.B. (2014). Expectation, perceived quality and satisfaction of Nigerian tourist in Malaysia. Master's dissertation, Universiti Utara Malaysia, Kedah, Malaysia. Available at: http://etd.uum.edu.my/4449/1/s806478 .pdf

Bland, J.M., \& Altman, D.G. (1997). Statistics notes: Cronbach's alpha. doi: https://doi.org/10.1136/bmj.314.7080.572

Bodycott, P., \& Lai, A. (2012). The influence and implications of Chinese culture in the decision to undertake cross-border higher education. Journal of Studies in International Education, 16(3), 252-270. https://doi.org/10.1177/1028315311418517

Byrd, E.T., Canziani, B., (Jerrie) Hsieh, Y.C., Debbage, K., \& Sonmez, S. (2016). Wine tourism: Motivating visitors through core and supplementary services. Tourism Management, 52, 19-29. https://doi.org/10.1016/j.tourman.2015.06.009

Cham, T.H., Lim, Y.M., Aik, N.C., \& Tay, A.G.M. (2016). Antecedents of hospital brand image and the relationships with medical tourist' behavioral intention. International Journal of Pharmaceutical and Healthcare Marketing, 10(4), 412-431. https://doi.org/10.1108/IJPHM-02-2016-0012

Chan, A., Hsu, C.H.C., \& Baum, T. (2015). The impact of tour service performance on tourist satisfaction and behavioral intentions: A study of Chinese tourists in Hong Kong. Journal of Travel and Tourism Marketing, 32(1-2), 18-33. https://doi.org/10.1080/10548408.2014.986010

Chand, M., \& Ashish, D. (2014). The impact of service quality on tourist satisfaction and loyalty in Indian tour operation industry. International Journal of Sales \& Marketing Management Research and Development (IJSMMRD), 4(5), 1-14.

Chang, I., Chou, P., Yeh, R.K., \& Tseng, H. (2016). Factors influencing Chinese tourists' intentions to use the Taiwan Medical Travel App. Telematics and Informatics, 32(2), 401-409. https://doi.org/10.1016/j.tele.2015.09.007

Chen, C.F., \& Chen, F.S. (2010). Experience quality, perceived value, satisfaction and behavioral intentions for heritage tourists. Tourism Management, 31(1), 29-35. https://doi.org/10.1016/j.tourman.2009.02.008

Chen, M.F., \& Tung, P.J. (2014). Developing an extended Theory of Planned Behavior model to predict consumers' intention to visit green hotels. International Journal of Hospitality Management, 36, 221-230. https://doi.org/10.1016/j.ijhm.2013.09.006.

Cheng, T., \& Lu, C. (2015). Destination image, novelty, hedonics, perceived value, and revisiting behavioral intention for island tourism. Asia Pacific Journal of Tourism Research, 18(7), 766-783. https://doi.org/10.1080/10941665.2012.697906

Cheon, J., Lee, S., Crooks, S.M., \& Song, J. (2012). An investigation of mobile learning readiness in higher education based on the theory of planned behavior. Computers and Education, 59(3), 1054-1064. https://doi.org/10.1016/j.compedu.2012.04.015

Chi, C.G.Q., \& Qu, H. (2008). Examining the structural relationships of destination image, tourist satisfaction and destination loyalty: An integrated approach Tourism Management, 29(4), 624-636. https://doi.org/10.1016/j.tourman.2007.06.007

Cohen, S.A., Prayag, G., \& Moital, M. (2014). Consumer behaviour in tourism: Concepts, influences and opportunities. Current Issues in Tourism, 17(10), 872-909. https://doi.org/10.1080/13683500.2013.850064

Crompton, J.L. (1979). Motivations for pleasure vacation. Annals of Tourism Research, 6(4), 408-424. https://doi.org/10.1016/0160-7383(79)90004-5

Cronbach, L.J. (1951). Coefficient alpha and the internal structure of tests. Psychometrika, 16(3), 291-334.

Dann, G.M.S. (2012). Tourist motivation and quality-of-life: In search of the missing link. Handbook of Tourism and Quality-of-Life Research, 233-250.

Doane, A.N., Pearson, M.R., \& Kelley, M.L. (2014). Predictors of cyberbullying perpetration among college students: An application of the Theory of Reasoned Action. Computers in Human Behavior, 36, 154-162. https://doi.org/10.1016/j.chb.2014.03.051

Dolnicar, S. (2010). Different Tourists - Different Perceptions of Different Cities Consequences for Destination Image Measurement and Strategic Destination Marketing. Analysing International City Tourism, 127-146.

Durie, A.D., \& Kebede, A.M. (2017). Determinants of tourist satisfaction: Evidence from tourist destination sites in Amhara Region, Ethiopia. Singaporean Journal of Business Economics and Management Studies, 5(8), 36-45. https://doi.org/10.12816/0037548

Eusébio, C., \& Vieira, A.L. (2011). Destination attributes' evaluation, satisfaction and behavioural intentions: A structural modelling approach. International Journal of Tourism Research, 15(1), 66-80. https://doi.org/10.1002/jtr

Ghosh, S.K., Islam, N., \& Bapi, A.B. (2018). The relationship between CSR, PSQ and behavioral intentions of hotel customers in Bangladesh. Journal of Management, 12(1), 1-15.

Hassan, M.M., \& Shahnewaz, M. (2014). Measuring tourist service satisfaction at destination: A case study of Cox's Bazar sea beach, Bangladesh. American Journal of Tourism, 3(1), 32-43. https://doi.org/10.5923/j.tourism.20140301.04

Hosany, S., \& Prayag, G. (2013). Patterns of tourists' emotional responses, satisfaction, and intention to recommend. Journal of Business Research, 66(6), 730-737. https://doi.org/10.1016/j.jbusres.2011.09.011

Hossain, A., Jamil, A.Al, \& Rahman, M. (2018). Exploring the key factors influencing consumers' intention, satisfaction and loyalty towards online purchase in Bangladesh. International Journal of Economics and Financial Research, 4(7), 214-225.

Hsu, C.H.C., \& Huang, S. (2012). An extension of the theory of planned behavior model for tourists. Journal of Hospitality and Tourism Research, 36(3), 390-417. https://doi.org/10.1177/1096348010390817

Huang, H.C. (2014). A Study on Tourist Satisfaction in Sanyi. International Journal of Innovation, Management and Technology, 5(4), 244-248. https://doi.org/10.7763/IJIMT.2014.V5.521

Huang, S. Sam, Weiler, B., \& Assaker, G. (2015). Effects of interpretive guiding outcomes on tourist satisfaction and behavioral intention. Journal of Travel Research, 54(3), 344-358. https://doi.org/10.1177/0047287513517426

Ifinedo, P. (2012). Understanding information systems security policy compliance: An integration of the theory of planned behavior and the protection motivation theory. Computers and Security, 31(1), 83-95. https://doi.org/10.1016/j.cose.2011.10.007

Jin, N., Lee, S., \& Lee, H. (2015). The effect of experience quality on perceived value, satisfaction, image and behavioral intention of water park patrons: New versus repeat visitors. International Journal of Tourism Research, 17(1), 82-95. https://doi.org/10.1002/jtr.

Kamal, M., Alam, S., \& Pramanik, K. (2015). Identifying factors influencing visitors to visit museums in Bangladesh and setting marketing strategies for museums. IOSR Journal of Business and ManagementVer. II, 17(10), 2319-7668. https://doi.org/10.9790/487X-171028592

Kautonen, T., van Gelderen, M., \& Fink, M. (2015). Robustness of the theory of planned behavior in predicting entrepreneurial intentions and actions. Entrepreneurship: Theory and Practice, 39(3), 655-674. https://doi.org/10.1111/etap.12056

Kim, D.J. (2012). An investigation of the effect of online consumer trust on expectation, satisfaction, and post-expectation. Information Systems and EBusiness Management, 10(2), 219-240. https://doi.org/10.1007/s10257-010-0136-2

Kim, H., \& Stepchenkova, S. (2015). Effect of tourist photographs on attitudes towards destination: Manifest and latent content. Tourism Management, 49, 29-41. https://doi.org/10.1016/j.tourman.2015.02.004

Kolvereid, L. (1996). Prediction of employment status choice intentions. Entrepreneurship Theory and Practice, 21(1), 47-58. https://oi.org/ $10.1177 / 104225879602100104$

Kong, W.H., \& Chang, T.Z. (Donald). (2016). Souvenir shopping, tourist motivation, and travel experience. Journal of Quality Assurance in Hospitality and Tourism, 17(2), 163-177. https://doi.org/10.1080/1528008X.2015.1115242

Krejcie, R.V., \& Morgan, D. (1970). Determining sample size for research activities. Educational and Psychological Measurement, 30, 607-610.

Kumar, A., Kumar, A., \& Rahman, Z. (2015). Tourist behaviour towards self-service hotel technology adoption: Trust and subjective norm as key antecedents. 
Tourism Management Perspectives, 16, 278-289. https://doi.org/10.1016/j.tmp.2015.09.002.

Lam, T., \& Hsu, C.H.C. (2004). Theory of planned behavior: Potential travelers from China. Journal of Hospitality and Tourism Research, 28(4), 463-482. https://doi.org/10.1177/1096348004267515

Lam, T., \& Hsu, C.H.C. (2006). Predicting behavioral intention of choosing a travel destination. Tourism Management, 27(4), 589-599. https://doi.org/10.1016/j.tourman.2005.02.003.

Lee, T.H. (2009). A structural model to examine how destination image, attitudes, and motivation affect the future behavior of tourists. Leisure Sciences, 31(3), 215-236. https://doi.org/ttps://doi.org/10.1080/01490400902837787

Li, M., \& Cai, L.A. (2012). The effects of personal values on travel motivation and behavioral intention. Journal of Travel Research, 51(4), 473-487. https://doi.org/10.1177/0047287511418366

Liao, C., Chen, J.L., \& Yen, D.C. (2007). Theory of planning behavior (TPB) and customer satisfaction in the continued use of e-service: An integrated model. Computers in Human Behavior, 23(6), 2804-2822. https://doi.org/10.1016/j.chb.2006.05.006

Liu, Y., Chen, Y., \& Zhou, C. (2006). Determinants affecting end-user satisfaction of information technology service. In Proceedings - ICSSSM'06: 2006 International Conference on Service Systems and Service Management. https://doi.org/ 10.1109/ICSSSM.2006.320509

Manning, M. (2009). The effects of subjective norms on behaviour in the theory of planned behaviour: A meta-analysis. British Journal of Social Psychology, 48(4), 649-705. https://doi.org/10.1348/014466608X393136

Matlovičová, K., \& Husárová, M. (2017). Potential of the heritage marketing in tourist destinations development. Folia Geographica, 59(1), 5-35.

Mishra, D., Akman, I., \& Mishra, A. (2014). Theory of Reasoned Action application for Green Information Technology acceptance. Computers in Human Behavior, 36, 29-40. https://doi.org/10.1016/j.chb.2014.03.030

Page, S.J., Essex, S., \& Causevic, S. (2014). Tourist attitudes towards water use in the developing world: A comparative analysis. Tourism Management Perspectives, 10, 57-67. https://doi.org/10.1016/j.tmp.2014.01.004

Paul, J., Modi, A., \& Patel, J. (2016). Predicting green product consumption using theory of planned behavior and reasoned action. Journal of Retailing and Consumer Services, 29, 123-134. https://doi.org/10.1016/j.jretconser.2015.11.006

Pearce, P.L. (2014). Tourism motivations and decision making. The Wiley Blackwell Companion to Tourism. https://doi.org/10.1002/9781118474648.ch3.

Phetvaroon, K. (2006). Application of the theory of planned behavior to select a destination after a crisis: A case study of Phuket, Thailand. Doctoral dissertation, Oklahoma State University, Stillwater, OK, United States. Available at: https://search-proquest-com.eserv.uum.edu.my/docview/ 304940021/1BDCCE16954B4B66PQ/6? accountid=42599

Prayag, G., \& Ryan, C. (2012). Antecedents of tourists' loyalty to mauritius: The role and influence of destination image, place attachment, personal involvement, and satisfaction. Journal of Travel Research, 51(3), 342-356. https://doi.org/10.1177/0047287511410321

Rajesh, R. (2013). Impact of tourist perceptions, destination image and tourist satisfaction on destination loyalty: A conceptual model. PASOS. Journal of Tourism and Cultural Heritage, 11(3), 67-78. https://doi.org/10.4090/juee.2008.v2n2.033040

Ryu, K., Han, H., \& Kim, T.H. (2008). The relationships among overall quick-casual restaurant image, perceived value, customer satisfaction, and behavioral intentions. International Journal of Hospitality Management, 27(3), 459-469. https://doi.org/10.1016/j.ijhm.2007.11.001

Sahli, A.B., \& Legohérel, P. (2014). Using the decomposed theory of planned behavior (DTPB) to explain the intention to book tourism products online. International Journal of Online Marketing, 4(1), 1-10. https://doi.org/10.4018/ijom.2014010101

Sheeran, P., \& Abraham, C. (2017). Implications of goal theories for the theories of reasoned action and planned behavior. Planned Behaviour. Routledge, New York.

Wang, Y. (2016). More important than ever: Measuring tourist satisfaction. Queensland, Australia. Available at: https://www.griffith.edu.au/_data/ assets/pdf_file/0029/18884/Measuring-Tourist-Satisfaction.pdf

Wu, L., Chen, K., Chen, P., \& Cheng, S. (2014). Perceived value, transaction cost, and repurchase-intention in online shopping: A relational exchange perspective. Journal of Business Research, 67(1), 2768-2776. https://doi.org/10.1016/j.jbusres.2012.09.007

Wu, M.Y., \& Pearce, P.L. (2014). Chinese recreational vehicle users in Australia: A netnographic study of tourist motivation. Tourism Management, 43, 2235. https://doi.org/10.1016/j.tourman.2014.01.010

$\mathrm{Xu}$, J., \& Chan, S. (2016). A new nature-based tourism motivation model: Testing the moderating effects of the push motivation. Tourism Management Perspectives, 18, 107-110. doi: 10.1016/j.tmp.2016.01.001

Yao, Y. (2013). Assessing tourist experience satisfaction with a heritage destination. Master Dissertation, Purdue University, West Lafayette, Indiana. https://doi.org/10.1177/1096348014525637

Ye, B.H. (2017). Intentions to participate in wine tourism in an emerging market: Theorization and implications. Journal of Hospitality \& Tourism Research, 41(8), 1007-1031. https://doi.org/10.1177/1096348014525637

*** Bangladesh Tourism Board. (2016). Tourist Attractions. Retrieved from http://www.tourismboard.gov.bd/

*** Bangladesh Tourism Board. (2020). Bangladesh Tourism Board. Tourist Attractions. Retrieved from http://www.tourismboard.gov.bd/ 